\title{
Factors Motivating Young South African Women to Become Entrepreneurs
}

\author{
Olawale Fatoki \\ Department of Business Management, Turfloop Campus, \\ University of Limpopo, Limpopo Province, South Africa \\ Email: Olawale.fatoki@ul.ac.za
}

\section{Doi:10.5901/mjss.2014.v5n16p184}

\begin{abstract}
The objective of the study was to investigate the factors that motivated young female entrepreneurs to start business. The study focused on young (not older than 35 years) female entrepreneurs that started business in the last forty two months. Female and youth entrepreneurship are significant to the reduction of high rates of unemployment and poverty in South Africa Data was collected through the use of self-administered questionnaires in a survey. Descriptive statistics was used for data analysis. The results indicated that there women have multiple motivations for starting business. Women entrepreneurs appear to be motivated by both push and pull factors. However, push factors are more significant.
\end{abstract}

Keywords: youth, female, entrepreneurship, motivators, South Africa

\section{Introduction}

South Africa suffers from high levels of unemployment and poverty. The unemployment rate is $25.2 \% \%$ (Statistics South Africa, 2014). Young people are vulnerable in the labour market. South Africa has the third highest unemployment rate in the world for people between the ages of 15 to 24 . More than $50 \%$ of young South Africans between 15 and 24 are unemployed (Global Risk, 2014). Turton and Herrington (2012) point out that that unemployed youths are more likely to engage in anti-social activities and descend into crime. In addition, women experience higher level of unemployment than men in South Africa. The unemployment rate of women is $2.9 \%$ higher than the national average (Statistics South Africa, 2010). Youth poverty is very high in South Africa. About $65.1 \%$ of children live in households that fall into the bottom two income quintiles and that have a per capita income of less than R650 a month (Statistics South Africa, 2010). In addition, female poverty is higher than male poverty in South Africa. Shisana et al. (2010) note that the feminization of poverty is increasingly apparent in South Africa.

Sharma and Madan (2014) assert that youth entrepreneurship is one of the solutions to youth unemployment and poverty. Governments across the world have recognized that the key to building prosperity is to foster entrepreneurship among their people especially the youth. Kamberidou (2013) argue that women-owned businesses make an increasingly important contribution to economies. Women entrepreneurs make a significant impact on the economy not only in their ability to create jobs for themselves, but also in creating jobs for others. Bosma et al. (2007) and Kelley et al. (2010) point out that research on women in development indicates that the returns on investment in women are much higher than for men. Women are more likely to work share their economic and noneconomic rewards with other people. Thus, investment in women's entrepreneurship is an important way for countries to significantly increase the impact of new venture creation.

According to Turton and Herrington (2012), the rate of enterprise creation is low in South Africa. Total Entrepreneurial Activity (TEA) rate decreased from $9.1 \%$ in 2011 to $7.3 \%$ in 2012. South Africa's TEA is significantly below the average of efficiency-driven countries (14.3). Youth and female entrepreneurship can help to improve the low rate of enterprise creation in South Africa. Zimmerman and Chu (2013) express that one recurring area of interest in the study of entrepreneurship is what motivates individuals to become entrepreneurs. According to Kirkwood (2009), individuals have various motivations for becoming an entrepreneur. Morris et al. (2006) affirm that the growth orientation of entrepreneurs is a function of motivation. The entrepreneur's motives for starting a business are a key element in predicting business performance (Robichaud et al. 2010). The motivating factors for entrepreneurship have stimulated research in many countries. The evidence is however mixed and inconclusive with respect to the level of importance of those factors (Kara et al. 2010). Understanding the reasons why young female individuals decide to start a business is important for the promotion of entrepreneurship in South Africa. 


\section{Objective of the Study}

Entrepreneurship is fundamental to the growth of the South African economy and its future socio-political stability. The creation and sustainability of new businesses are vital to the economic prosperity of South Africa. The objective of the study is to investigate the factors that motivated young female entrepreneurs to start business.

\section{Literature Review}

\subsection{Definition of entrepreneurship}

Gedeon (2010) points out that the term entrepreneurship (or who is an entrepreneur) lacks a single unified and accepted definition. The literature is replete with criteria ranging from creativity and innovation to personal traits such as appearance and style (Fernald et al. 2005). According to Gedeon (2010), Cantillon, Turgot, Say and Schumpeter laid the foundations for the meaning of entrepreneurship. Cantillon defines the entrepreneur as someone who assumes the risk and may legitimately appropriate any profits. Turgot and Say point out that the entrepreneur obtains and organizes production factors to create value. Schumpeter (1934) relates entrepreneurship to innovation. The innovative activity of entrepreneurs feeds a creative "destruction process" by causing constant disturbances to an economic system in equilibrium, creating opportunities for economic rent. In adjusting to equilibrium, other innovations are spun-off and more entrepreneurs enter the economic system. McCleland (1961) asserts that entrepreneurial activity involves risk-taking, energetic activity, individual responsibility, money as a measure of results, anticipation of future possibilities, and organizational skills. Drucker (1985) notes that the entrepreneur always searches for change, responds to it, and exploits it as an opportunity. Innovation is the tool of entrepreneurship Rwigema and Venter (2004) define entrepreneurship as the process of conceptualising, organising, launching and through innovation, nurturing a business opportunity into a potentially high growth venture in a complex and unstable environment. Entrepreneurship is a vehicle to economic growth, success and prosperity. Herrington et al. (2009) point out that an entrepreneur is one that shifts economic resources out of an area of low productivity into an area of higher productivity and greater yield. An entrepreneur is one who organises, manages and assumes the risk of a business enterprise. According to Sathiabama (2010), entrepreneurship is a dynamic process of creating wealth by individuals or groups of individuals. The term small business owner is often used as a synonym for an entrepreneur (Aaltonen and Akola, 2014).

\subsection{Youth entrepreneurship}

The African Youth Charter (2006) defines a youth as a person between the ages of 15 and 35 years. The National Youth Policy (2009) describes young people in South Africa as "those falling within the age group of 14 to 35 years". According to Yu (2013), one of South Africa's most pressing socio-economic problems is high youth unemployment. Youths do not have the necessary network to acquire information on job opportunities. In addition, youths do not have the as well as financial resources and mobility to seek work or relocate closer to the places where job opportunities are available. More than 50\% of young South Africans between 15 and 24 are unemployed (Global Risk, 2014). One of the solutions to youth unemployment and poverty is entrepreneurship (Sharma and Madan 2014).

Chigunta (2002) defines youth entrepreneurship as "the practical application of enterprising qualities, such as initiative, innovation, creativity, and risk-taking into the work environment (either in self-employment or employment in small start-up firms), using the appropriate skills necessary for success in that environment and culture." Chigunta (2002) adds that youth entrepreneurship helps to address the problems associated with joblessness such as crime and depression, promoting innovation and resilience in youth, the regeneration of the local community and the introduction of new economic opportunities and trends by young entrepreneurs. Youth's natural disposition for innovation and change make young people well suited for entrepreneurship. Youth entrepreneurship can help young people to acquire the skills and competencies that they will need at work. Lourenco et al. (2013) point out that the development of an entrepreneurial mind-set and/or enterprising skills is on the agenda for developing graduates in order to enhance their employability. Employers are looking for graduates equipped with skills that will enable them to act in enterprising ways so they can deal effectively with a difficult business environment, and a personal life that is increasingly full of uncertainties and complexities.

According to Chigunta (2002), youth entrepreneurs can be classified into three groups. (1) Pre-Entrepreneurs: Usually the youngest and greenest of the youth entrepreneurs. Typically 15-19 years of age and without much experience. They are usually at an experiential stage, testing future career options. (2) Budding Entrepreneurs: These are 
the next-stage youth entrepreneurs typically aged 20-24 years of age and with some experience, confidence and capital. (3) Emergent Entrepreneurs: These entrepreneurs are at the prime phase of the transition. They are usually the most experienced of the youth entrepreneurs and have access to greater capital.

\subsection{Female entrepreneurship}

According to Statistics South Africa (2011), the scales remain tilted in favour of men with regards to education and literacy, employment and financial standing. The average annual household expenditure is higher for male-led homes compared to women-led homes. Women experience far higher level of unemployment compared to men. The unemployment rate of women is $2.9 \%$ higher than the national average. Grant and Hallman (2006) point out that young women in South Africa face specific challenges and particular difficulties. Young women are more likely to be unemployed than males, since they tend to have fewer occupational opportunities in a patriarchal society. The poverty rate of women is higher than that of men in South Africa. There is the increasing feminisation of poverty in South Africa (Shisana et al. 2010). Entrepreneurship is one of the solutions to female unemployment and poverty (Kamberidou, 2013).

Buttner \& Moore (1997) defines a female entrepreneur as "a woman who has initiated a business, is actively involved in managing it, owns at least 50 percent of the firm, and that the business has been in operation one year or longer". Sharma (2013) defines a female entrepreneur as a "woman or a group of women who initiate, organize and run a business enterprise". In the context of this study, a woman entrepreneur is described as someone who owns or manages a small business.

Acs et al. (2005) argue that one of the reasons for the increasing importance attached to women entrepreneurship is the significant role that female entrepreneurs play in creating, running and developing businesses. Female entrepreneurs act as a fundamental driver of economic growth. Mitchelmore and Rowley (2013) point out that in 2010, 104 million women in 59 economies representing more than 52 per cent of the world's population and 84 per cent of world GDP embarked on new venture creation and development. Kamberidou (2013) points out that women-owned businesses make an increasingly important contribution to economies. Women entrepreneurs have a significant impact on the economy not only in their ability to create jobs for themselves, but also in creating jobs for others. Bosma et al. (2007) and Kelley et al. (2010) point out that research on women in development indicates that the returns to the investment in women are much higher than for men. Women are more likely to work share their economic and noneconomic rewards with other people. Thus, investment in women's entrepreneurship is an important way for countries to significantly increase the impact of new venture creation. Disregarding the recognised potential of women's entrepreneurial activity put countries at a disadvantage and hinders their opportunity to increase economic growth. This implies that finding ways to empower women's participation and success in entrepreneurship is critical to a country's sustainable economic development. Integrating a gender perspective to entrepreneurship implies eliminating the wastage of talent and the utilisation of the entire talent pool. This boosts innovation which is a pre-condition for economic growth and sustainable development (Kamberidou 2013). According to Kepler and Shane (2007), businesses that are owned by women are more likely to have positive revenues. This is because women entrepreneurs have a tendency to minimise risk so that their business and personal lives work in harmony.

\subsection{Motivations for entrepreneurship}

Zimmerman and Chu (2013) express that one recurring area of interest in the study of entrepreneurship is what motivates individuals to become entrepreneurs. According to Kirkwood (2009), individuals have various motivations for becoming an entrepreneur and there are four key drivers of entrepreneurial motivation according to the literature. These are (1) desire for independence (2) monetary motivation (3) motivation related to work such as unemployment, redundancy, a lack of job or career prospect and (4) family related motivations. Robichaud et al. (2001) find that the motivation of entrepreneurs falls into four distinct categories: (1) Extrinsic rewards (2) independence/autonomy (3) intrinsic rewards and (4|) family security. Swierczek and $\mathrm{Ha}(2003)$ find that SME owners in Vietnam are more motivated by challenge and achievement than the necessity for a career and economic security. Carter et al. (2003) reveal that the most popular motivating factor is the desire for an individual to achieve financial security. Chu et al. (2007) find that for Kenyan and Ghanaian entrepreneurs, increasing their income and creating jobs for themselves are the leading factors motivating them to become business owners. Benzing et al. (2009) find that the three most important motivators are to increase income, to have job security and to maintain personal freedom and independence.

Stefanović et al. (2011) point out that high levels of achievement motivation are consistent with the demands of entrepreneurial role. Achievement motivation appears to be an important characteristic for entrepreneurs. Krishna (2013) 
ascertains that motivational factors can be classified into internal and external factors. Internal factors are related to the personality of the entrepreneur and generate an inclination to adopt entrepreneurial activity. Internal factors include educational background, occupational experience, the desire to do something pioneering and innovative, the desire to be free and independent and family background. Entrepreneurial ambitions cannot fructify without a supporting environment. External factors provide support and give a spark to entrepreneurship. External factors include assistance from government and financial assistance from institutions.

Kirkwood (2009) and Charles and Gherman (2013) establish that motivations can be classified under push and pull factors. Push factors are those influences that push individuals toward entrepreneurship. Pull factors are those influences that pull people towards entrepreneurship. Push factors are characterised by personal or external factors. This category includes issues such as unemployment, redundancy, and a lack of job or career prospects. Pull factors are those that draw people to start businesses. This category includes opportunity identification. Kirkwood (2009) classifies the desire for independence and monetary motivation especially wealth creation as pull factors. Motivations to become an entrepreneur that relate to work are considered as push factors. Family-related motivations for becoming an entrepreneur are classified as push factors. This category includes a fit with and a desire for work-family balance. Islam (2012) and Charles and Gherman (2013) assert that push factors are those motivators characterised by personal or external factors. These include the need to support the family with additional income, difficulty in finding work, divorces, economic recession and job losses. Pull factors are those motivators related to opportunity and superior needs. These include independence, personal growth, self- fulfilment, social status, financial motivation and power. According to Bohla et al. (2006), push and pull factors can be compared to necessity-based entrepreneurship and opportunity-based entrepreneurship, Opportunity entrepreneurs are influenced by pull factors to start a business, while necessity entrepreneurs are affected by push factors.

Turning specifically to women entrepreneurs, Moore (2003) finds that no single factor motivates women to become an entrepreneur. Women business owners cite a number of reasons for becoming entrepreneurs. The motivating factor for women entrepreneurs include challenges/attractions of entrepreneurship, self-determination/autonomy, family concerns, lack of career advancement and the desire to make a social contribution. Robichaud et al (2010) find that that female small business owners are motivated by intrinsic factors as opposed to monetary motives. Charles and Gherman (2013) also find that the most important factors motivating women entrepreneurs are personal growth, social mission and interpersonal relationships. Financial motivation is also important but not the primary motivator. In addition, women seem to be motivated by pull factors and not by necessity.

Chigunta (2002) summarises the research on the motivating factors for youth entrepreneurs and concludes that the motivating factors appear to be different in developed countries compared to developing countries. In developed countries, the motivators include to be one's own boss, to obtain an alternative route for advancement, to obtain additional money, the desire for independence and flexibility. In developing countries, youth entrepreneurship appears to be motivated by economic necessity such as lack of employment, the need to supplement household income and not the need to accumulate wealth. This suggests that youth are pushed into entrepreneurship by the need to survive.

\section{Research Methodology}

The survey focused on female owners of new micro enterprises. According to the Parliament of the Republic of South Africa (1995), a micro enterprise is a business with (1) total full-time equivalent of paid employee of less than 5 (2) total annual turnover of less than R150,000 and (3) total gross asset value (fixed property excluded) of less than R100,000. The study used the number of employees to determine a micro enterprise. Maas and Herrington (2006) point out that a new enterprise can be described as a business that has been in existence for a period not longer than forty two months. Data was collected through the use of self-administered questionnaires in a survey. The survey was conducted in Polokwane and Mankweng in the Limpopo province of South Africa. Because of the difficulty in obtaining the population of micro-enterprises in the study area, purposive sampling and the snowball sampling methods were used. A pilot study was conducted on the survey instrument used in this research with ten on female owners of new micro enterprises in order to ensure face and content validity. Owners were assured of confidentiality with regard to the data collected. The questionnaires were given to the owners of the micro-enterprises to complete. The questionnaire was divided into two parts (1) biographical information (2) motivating factors. To measure motivational factors for entrepreneurship, an eighteen item questionnaire was developed for the study. The questionnaire was adapted from previous studies on the motivating factors for entrepreneurship such as Benzing et al. (2009), Robichaud et al. (2010), Chu et al. (2011) and Singh et al. (2011). The measuring instruments from these studies achieved high levels of reliability. Five point Likert scale questions ranging from " 5 extremely important", 4 very important, 3 "mildly important, 2 not very important and 1 
unimportant" were used. The Cronbach's alpha was 0.739 indicating the reliability of the survey instrument. Nunnally (1978) points out that the Cronbach's alpha score should be above 0.70 . Descriptive statistics was used for data analysis.

\section{Results and Discussions}

41 questions were distributed and 17 returned. The response rate was $41.4 \% .10$ respondents have Matric qualification and 7 respondents have post matric qualification. 10 respondents are in retail sector and 7 respondents are in the service sector. 13 respondents do not have any full-time employee, 3 respondents have one full-time employees and 1 respondent has two full-time employees.

Table 1: Motivational factors for entrepreneurship

\begin{tabular}{|l|c|c|}
\hline Motivational Factors & Mean & Standard deviation \\
\hline To have a job & 4.55 & 1.082 \\
\hline To increase my income & 4.48 & 0.927 \\
\hline There is the market for my product (service) & 4.22 & 0.764 \\
\hline For my own satisfaction and growth & 3.96 & 0.778 \\
\hline Accessibility to personal finance to start business & 3.90 & 1.090 \\
\hline To be able to use my past experience and training & 3.65 & 0.756 \\
\hline To have job security & 3.57 & 0.782 \\
\hline To maintain my personal freedom & 3.52 & 0.659 \\
\hline To provide for my family & 3.40 & 0.974 \\
\hline I like to take risk & 3.25 & 0.752 \\
\hline To prove that I can do it & 3.05 & 0.675 \\
\hline To be my own boss & 3.02 & 0.724 \\
\hline Desire for self-achievement & 3.02 & 0.629 \\
\hline I was not challenged by my previous work & 2.05 & 0.649 \\
\hline To be closer to my family & 1.25 & 0.726 \\
\hline To gain public recognition & 1.25 & 0.535 \\
\hline To have fun & 1.14 & 0.538 \\
\hline To build a business to pass on & 1.10 & 0.529 \\
\hline
\end{tabular}

Table 1 presents the motivating factors for the respondents who owners of micro enterprises. The results indicate that the two most important motivating factors are to have a job and to increase income. Statistics South Africa (2011) points out women experience far higher level of unemployment compared to men in South Africa. Chigunta (2002) observes that in developing countries, youth entrepreneurship appears to be motivated by economic necessity such as lack of employment, the need to supplement household income. In the context of the push-pull motivation factors, the primary reason for entrepreneurship by young female entrepreneurs can be classified as push factors. Entrepreneurship is a means to survival. Islam (2012) and Charles and Gherman (2013) assert that push factors are those motivators characterised by personal or external factors. These include the need to support the family with additional income, difficulty in finding work, divorces, economic recession and job losses.

In the context of necessity and opportunity motivation factors, the results indicate that the primary motivators for entrepreneurship are necessity factors. According to Bohla et al. (2006), push and pull factors can be compared to necessity-based entrepreneurship and opportunity-based entrepreneurship. Opportunity entrepreneurs are influenced by pull factors to start a business, while necessity entrepreneurs are affected by push factors. Block and Wagner (2010) point out that opportunity entrepreneurs are entrepreneurs who start a business in order to pursue an opportunity, while necessity entrepreneurship is more need-based. The results are consistent with the findings of previous empirical studies on the motivating factors for entrepreneurship. Chu et al. (2007) find that for Kenyan and Ghanaian entrepreneurs, increasing their income and creating jobs for themselves are the leading factors motivating them to become business owners. Benzing et al. (2009) find that the three most important motivators are to increase income, to have job security and to maintain personal freedom and independence. In addition, "there is a market for products and satisfaction and growth" are also important motivators. These are pull factors. Charles and Gherman (2013) assert that pull factors are those motivators related to opportunity and superior needs. The results suggest that push (necessity) factors are the most significant motivating factors for young female entrepreneurs. However, some pull (opportunity) factors are also important motivators. Kirkwood (2009) finds that entrepreneurs are not motivated by a single factor, and there are multiple 
motivations for starting a new business. The motivations for entrepreneurship are complex and intertwined. Women entrepreneurs are motivated by both push and pull factors.

\section{Conclusions}

The objective of the study was to investigate the factors that motivated young female entrepreneurs to start business in South Africa. The survey focused on female owners of new micro enterprises. Youth entrepreneurship helps in creating of employment opportunities for both the self-employed youth and other young people. Women entrepreneurs make a significant impact on the economy not only in their ability to create jobs for themselves, but also in creating jobs for others. The results indicated that the two most important motivating factors are to have a job and to increase income. In the context of the push-pull motivation factors, the primary reason for entrepreneurship by young female entrepreneurs can be classified as push factors. Entrepreneurship is a means to survival. The results also indicated that some pull factors are also important motivators. The results suggest that there are multiple motivations for starting a new business. Women entrepreneurs appear to be motivated by both push and pull factors. However, push factors seem to be more significant. A major limitation of the study is the small number of participants in the study. Thus, caution must be taken in interpreting the findings and in making generalisations. Data collection could be expanded to include a larger sample of young female entrepreneurs in South Africa.

\section{References}

Aaltonen Satu \& Akola, Elisa (2014), Lack of trust: the main obstacle for immigrant entrepreneurship? [Online] Available: http://pyk2.aalto.fi/ncsb2012/Aaltonen.pdf (March 15, 2014)

Acs Zoltan, Arenius Pia, Hay, Michael \& Minniti, Maria (2005), Global Entrepreneurship Monitor 2004 Exectitve Report. [Online] Available: http://www.gemconsortium.org/docs/260/gem-2004-global-report (April 7, 2014)

The African Youth Charter (2006) A Framework defining Africa's Youth Agenda. [Online] Available: http://africa-youth.org/charter (April 2, 2014)

Benzing, C., Chu, H. \& Kara, O. (2009). Entrepreneurs in Turkey: A factor analysis of motivations, success factors, and problems. Journal of Small Business Management, 47(1), 58-91.

Bhola, Reena, Verheul, Ingrid, Grilo, Isabel \& Thurik, Roy (2006), Explaining engagement levels of opportunity and necessity entrepreneurs. [Online] Available: http://repub.eur.nl/pub/9705/EIM20070208003_H200610.pdf (March 8, 2014)

Bosma, Niels, Jones, Kent, Autio, Erkko \& Levie, Jonathan (2007), GEM 2007 Global Report [Online] Available: http://www.gemconsortium.org/docs/download/263 (March 15, 2014)

Buttner, E.H., \& Moore, D. (1997) Women's organizational exodus to entrepreneurship: Self-reported motivations and correlates with success. Journal of Small Business Management, 35(1): 34-46.

Carter, N.M., Gartner, W. B., Shaver, K. G., \& Gatewood, E. J. (2003). The career reasons of nascent entrepreneurs. Journal of Business Venturing, 18(1): 13-39.

Charles, V., \& Gherman T. (2013). Factors Influencing Peruvian Women to Become Entrepreneurs. World Applied Sciences Journal, 27 (10): $1345-1354$

Chigunta, Francis (2002), Youth Entrepreneurship: Meeting the Key Policy Challenges [Online] Available: yesweb.org/gkr/res/bg.entrep.ta.doc (March 2, 2014)

Chu, H. M., Benzing, C., \& McGee C. (2007). Ghanaian and Kenyan Entrepreneurs: A Comparative Analysis of Their Motivations, Success Characteristics, and Problems. Journal of Developmental Entrepreneurship, 12(3), 295-322.

Chu, H.M., Kara, O., Zhu, X., \& Gok, K (2011) Chinese entrepreneurs: Motivations, success factors, problems, and business-related stress. Journal of Chinese Entrepreneurship, 3(2): 84 - 111

Drucker P.F. (1985) Innovation and Entrepreneurship, London: Pan Books Ltd.

Gedeon, S. (2010). What is Entrepreneurship? Entrepreneurial Practice Review, 1(3):16-35

Global risks (2014). World Economic Forum [Online] Available: http://www3.weforum.org/docs/WEF_GlobalRisks_Report_2014.pdf (March 15, 2014)

Grant, Monica, \& Hallman, Kelly (2006), Pregnancy-related school dropout and prior school performance in South Africa. [Online] Available: http://www.popcouncil.org/uploads/pdfs/wp/212.pdf (March 2, 2014)

Herrington, Mike, Kew, Jacqui, Kew, Penny (2009), Global Entrepreneurship Monitor, South African Report. [Online] Available: http://www. gbs.nct.ac.za/gbswebb/userfiles/gemsouthafrica 2000pdf (October 15, 2013).

Kamberidou, I. (2013). Women entrepreneurs: we cannot have change unless we have men in the room. Journal of Innovation and Entrepreneurship, 2(6) 1-18

Islam, S. (2012). Pull and push factors towards small entrepreneurship development in Bangladesh. Journal of Research in International Business Management, 2(3): 65-72

Kara, O., Chu, H.M., \& Benzing, C (2010). Determinants of entrepreneur's success: evidence from Turkey. Journal of Business and Entrepreneurship, 22(2)1-15. 
Kelley, Donna, Bosma, Niels, \& Amorós, José Ernesto (2010), . GEM Global Report [Online] Available: http://www.gemconsortium.org (January 15, 2014).

Kepler, Erin \& Shane, Scott (2007), Are Male and Female Entrepreneurs Really That Different? [Online] Available http://www.pw.seipa.edu.pl/s/p/artykuly/90/909/Female\%20Entrepreneurs\%20Different\%20Shane\%202007.pdf (January 18, 2014).

Kirkwood, J. (2009). Motivational factors in a push-pull theory of entrepreneurship. Gender in Management: An International Journal, 24(5): 346-364

Krishna. S.M (2013). Entrepreneurial Motivation: A Case Study of Small Scale entrepreneurs in Mekelle, Ethiopia. Journal of Business Management \& Social Science Research, 2(1): 1-6.

Lourenço, F., Taylor, T.G., \& Taylor, D.W. (2013) .Integrating education for entrepreneurship in multiple faculties in "half-the-time" to enhance graduate entrepreneurship. Journal of Small Business \& Enterprise Development, 20(3): 503 -525.

Maas Gideon \& Herrington Mike (2006). Global Entrepreneurship Monitor South African Report. [Online] Available:http:/l www.gemconsortium.org/document.aspx?id756 (January 15, 2014).

McClelland, D.C. (1961). The achieving society. Princeton, NJ: Van Nostrand.

Mitchelmore, S., \& Rowley, J (2013). Entrepreneurial competencies of women entrepreneurs pursuing business growth. Journal of Small Business and Enterprise Development, 20(1):125-142

Moore, D.P. (2003) Women: Are You Ready to Be Entrepreneurs?. Business \& Economic

Review, 49(2): 15-21.

Morris, M.H., Miyasaki, N.N., Watters, C.E., and Coombes, S.M. (2006). The Dilemma of Growth: Understanding Venture Size Choices of Women Entrepreneurs. Journal of Small Business Management, 44(2), 221-244.

National Youth Policy (2009). National Youth Policy 2009-2014 [Online] Available: http://www.thepresidency.gov.za /MediaLib/Downloads/Home/Publications/YouthPublications/NationalYouthPolicyPDF/NYP.pdf (January 2, 2014).

Nunnally J.C (1978). Psychometric Theory, 2nd ed. New York: McGraw-Hill.

Parliament of the Republic of South Africa (1995), The White Paper on National Strategy for the Development and Promotion of Small Business in South Africa. [Online] Available http://www.info.gov.za/whitepapers/1995/small bus.html (January 2, 2014).

Robichaud, Y., McGraw, E., \& Roger, A. (2001). Toward the Development of a Measuring Instrument for Entrepreneurial Motivation. Journal of Developmental Entrepreneurship, 6(1), 189-202.

Robichaud, Y., LeBrasseur, R., \& Nagarajan K.V. (2010). Necessity and Opportunity-driven Entrepreneurs in Canada: An Investigation into their Characteristics and an Appraisal of the Role of Gender. Journal of Applied Business and Economics, 11(1): 59-80.

Rwigema, H., \& Venter, R. (2004). Advanced entrepreneurship. Advanced Entrepreneurship. Cape Town: Oxford University Press Southern Africa.

Sathiabama, K. (2010), Rural women empowerment and entrepreneurship development. [Online] Available Available: http://www.microfinancegateway.org/ga (August 15, 2010].

Singh, S., Simpson, R., Mordi, C., \& Okafor, C (2011). Motivation to become an entrepreneur: a study of Nigerian women's decisions. African Journal of Economic and Management Studies, 2(2): 202 - 219

Stefanovic, I., Rankovic, L., \& Prokic S (2011) Entrepreneurs' motivational factors: empirical evidence from Serbia. Serb Journal of Management, 6(11):73-84

Swierczek, F., \& Ha T.T (2003). Motivation, Entrepreneurship, and Performance of SMEs in Vietnam, Journal of Enterprising Culture, 11(1), 47-68.

Sharma Y (2013). Women Entrepreneur In India. IOSR Journal of Business and Management, 15(3): 9-14

Sharma, L., \& Madan, P (2014), Effect of individual factors on youth entrepreneurship - a study of Uttarakhand state, India. Journal of Global Entrepreneurship Research, 2(3): 1-17

Shisana, O., Rice, K., Zungu, N., \& Zuma K (2010). Gender and Poverty in South Africa in the Era of HIVIAIDS: A Quantitative Study. Journal of Womens Health, 19(1): 39-46

Statistics South Africa (2010), Social profile of South Africa, 2002-2009. [Online] Available http://www.statssa.gov.za /publications/Report-03-19-00/Report-03-19-002009.pdf (March 18, 2014)

Statistics South Africa (2011) . Gender Statistics in South Africa [Online] Available http://www.statssa.gov.za/publications/Report-03-1005/Report-03-10-052011.pdf (January 2, 2014).

Statistics South Africa (2014). Quarterly Labour Force Survey. [Online] Available http: http://beta2.statssa.gov.za/ (May 5, 2014)

Turton, Natasha, \& Herrington, Mike, (2013). Global Entrepreneurship Monitor South African 2012 Report. [Online]. Available: http://www.gemconsortium.org/docs/2801/gem-south-africa-2012-report (December 22, 2013)

Zimmerman, M.A., \& Chu H.M ( 2013). Motivation, Success, and Problems of Entrepreneurs in Venezuela. Journal of Management Policy and Practice, 14(2)76-90 